\title{
Plant Species Selection for Charcoal Production: Dwindling Resource and Further Implications for the Environment
}

\author{
Philomena Kumapley and Christopher Dumevi \\ Department of Silviculture and Forest Management, Faculty of Renewable Natural Resources, Kwame Nkrumah University of \\ Science and Technology, Kumasi, Ghana
}

\begin{abstract}
The authors investigated plant species selected for charcoal production. Then, they compared these species with those exploited for charcoal production in Togo, another West African country. The study in Ghana took place in six localities in the Volta Region. Simple ranking was used in the analysis of the species. A total of 35 species belonging to 31 genera were used. Five of these are non-traditional charcoal-making species, implying the increasing diversity of the plants used. Anogeissus leiocarpus ranked first with over $79 \%$ of the producers exploiting it and was reported as a preferred or a category 1 species for charcoal production in Togo. Out of the 34 woody species exploited in Togo, 10 are similar to those used in the study area. The ranking used are compared favourably with the categorization used in the Togolese studies.
\end{abstract}

Key words: Volta Region, Ghana, Togo, ranking, categorization, non-traditional charcoal-making species.

\section{Introduction}

Charcoal, used mostly as energy for cooking in Africa, is produced through the thermal degradation of wood. Onishi [1] stated that charcoal, cleaner and easier to use than firewood, and cheaper and more readily available than gas or electricity, has become one of the biggest engines of Africa's informal economy and has also become one of the greatest threats to its environment. The environmental impacts include land degradation, global warming and climate change.

According to Kammen et al. [2], charcoal use in developing countries affects global warming in several interrelated ways. This is because in the first place a significant portion of charcoal production wood is unsustainably harvested. Secondly, emissions during charcoal production are significant compared to those of charcoal burning, One of the gases emitted is $\mathrm{CO}_{2}$. Ref. [3] advised that reducing $\mathrm{CO}_{2}$ emissions limits

Corresponding author: Philomena Kumapley, Ph.D., main research field: charcoal production. the ultimate amount of warming because $\mathrm{CO}_{2}$ represents by far the largest source of climate-warming emissions and because it stays in the atmosphere for hundreds of years, large reductions in $\mathrm{CO}_{2}$ emissions are required to meet any long-term climate-stabilization goals. Climate change has impacts and Waugh [4] therefore, recommends that modest investment will increase people's ability to assess local vulnerability to the impacts of climate change. One area of vulnerability is the resource for charcoal production: its quantity and quality. The resource is dwindling [5]. In terms of quality and the quality of charcoal produced, the wood species selected is important. A general guide which stated that all hardwoods used as fuel-wood are generally suitable for the manufacture of charcoal was given by Abbiw [6]. However, Pereira et al. [7] working on clones of Eucalyptus for charcoal production gave a scientific perspective. According to their findings, although several properties of wood should be considered together, basic density and chemical composition of wood in particular, high contents of 
lignin and low contents extractives were the properties that had more influence on charcoal yield and quality. The objectives of this study, therefore, were to (1) determine the species of wood selected for charcoal production and (2) to compare these species with those reported for another country.

\section{Methodology}

The study was examined in six localities in the Volta Region of Ghana: 4 localities in Adaklu and 2 in Akoefe. The details are shown in Table 1. Data collection was done using questionnaires and data analysis was done using simple ranking.

The ranked species were then compared with those reported in the literature for the neighbouring country of Togo.

\section{Results}

Out of a total of 152 charcoal producers, the majority was male and $43.4 \%$ were females (Table 2 ).

\subsection{Species Selected for Charcoal Production}

A total of 35 species were mentioned as charcoal-producing species (Table 3). Four of the genera had two species each. These were Acacia, Cola, Ficus and Vitex. The 35 species were ranked from the first to the 29th positions. Almost $80 \%$ of the charcoal producers used Anogeissus leiocarpus.

\subsection{Species Being Newly Exploited for Charcoal Production}

Table 4 shows that almost $14 \%$ of the species exploited are non-traditional charcoal-making species. The ranking which gave some idea of the level of exploitation showed that the first of these non-traditional species Prionostemma unguiculata was fairly exploited, ranking fourth among the 35 species.

3.3 Similarities between Species Exploited for Charcoal Production in the Study Area (Ghana) and Togo (another West African Country)

Table 5 shows the same species that were exploited in the two West African countries, Ghana and Togo, for charcoal production. Table 5 shows that the ranking and the categorization give similar ideas about the choice of the charcoal producers.

\section{Discussion}

A total of 35 woody plant species were selected for charcoal production in the study area. One of the species, a species noted for its excellent charcoal production qualities, Anogeissus leiocarpus, was obviously under intense exploitation pressure being used by almost $80 \%$ of the charcoal producers interviewed. It is one of the 34 species used in Togo and described as one of the preferred or category 1 species $[9,10]$. The future of this species in the sub-region is at stake. Some of the 35 species are forest species and others occur in the savannas or woodlands $[6,11,12]$. These 35 species occurred in 31 genera. Species belonging to a genus are expected to behave in a similar manner. Five of the species were non-traditional charcoal-making species. A non-traditional charcoal-making species used for charcoal production was reported earlier among the 23 species utilized by the charcoal producers in a cacao-growing area in the Ashanti Region of Ghana [13]. This species was Amphimas

Table 1 Study sites.

\begin{tabular}{lll}
\hline Country & Administra-tive Region & Sites \\
\hline Ghana & Volta Region & Adaklu Have \\
& & Adaklu Helekpe \\
& & Adaklu Kodzobi \\
& & Adaklu Vodze \\
& & Akoefe Avenui \\
& & Akoefe Achati \\
\hline
\end{tabular}


Table 2 Gender of the charcoal producers.

\begin{tabular}{lll}
\hline Gender & Number & Percentage \\
\hline Males & 86 & $56.6 \%$ \\
Females & 66 & $43.4 \%$ \\
Total & 152 & $100 \%$ \\
\hline
\end{tabular}

Table 3 Plant species selected for charcoal production in Volta Region of Ghana.

\begin{tabular}{|c|c|c|}
\hline S/lN Species & Percentage & Rank \\
\hline 1. Anogeissus leiocarpus & 79.97 & $1 \mathrm{st}$ \\
\hline 2. Acacia nilotica & 48.7 & 2nd \\
\hline 3. Detarium senegalense & 42.4 & $3 \mathrm{rd}$ \\
\hline 4. Prionostemma unguiculata & 36.9 & 4 th \\
\hline 5. Terminalia glaucescens & 34.9 & 5 th \\
\hline 6. Bridelia micrantha & 32.9 & 6th \\
\hline 7. Vitellaria paradoxa & 22.4 & 7 th \\
\hline 8 Azadirachta indica & 14.5 & 8 th \\
\hline 9. Icacina oliviformis & 9.2 & 9th \\
\hline 10. Dialium guineense & 9.2 & 9th \\
\hline 11. Ficus sur (= Ficus capensis $)$ & 7.9 & 11th \\
\hline 12.Piliostigma thonningii & 6.6 & 12 th \\
\hline 13, Daniella oliveri & 5.9 & 13th \\
\hline 14. Cathormion altissimum & 5.9 & 13th \\
\hline 15. Senna siamea & 5.3 & 15 th \\
\hline 16. Ficus laprueri & 2.6 & 16 th \\
\hline 17. Tectona grandis & 2.6 & 16 th \\
\hline 18. Acacia auriculiformis & 2 & 18 th \\
\hline 19. Gardenia nitida & 2 & 18 th \\
\hline 20. Lannea sp, & 2 & 18th \\
\hline 21. Blighia sp. & 1.3 & $21 \mathrm{st}$ \\
\hline 22. Cola nitida & 1.3 & $21 \mathrm{st}$ \\
\hline $\begin{array}{l}\text { 23. Zanthoxylum xanthxyloides } \\
\text { (= Fagara xanthoxyloides) }\end{array}$ & 1.3 & $21 \mathrm{st}$ \\
\hline 24. Gliricidia sepium & 1.3 & $21 \mathrm{st}$ \\
\hline 25. Mangifera indica & 1.3 & $21 \mathrm{st}$ \\
\hline 26. Triplochiton scleroxylon & 1.3 & $21 \mathrm{st}$ \\
\hline 27. Hymenocardia acida & 1.3 & $21 \mathrm{st}$ \\
\hline 28. Maytenus senegalensis & 1.3 & $21 \mathrm{st}$ \\
\hline 29. Antiaris africana & 0.7 & 29th \\
\hline 30. Cola gigantean & 0.7 & 29th \\
\hline 31. Leucaena leucocephala & 0.7 & 29th \\
\hline 32. Milicia excels & 0.7 & 29th \\
\hline 33. Vitex doniana & 0.7 & 29 th \\
\hline 34. Vitex glabrata & 0.7 & 29th \\
\hline 35. Parkia biglobosa & 0.7 & 29th \\
\hline
\end{tabular}

Table 4 Non-traditional charcoal-making species and their ranks.

\begin{tabular}{ll}
\hline S/N Species & Rank \\
\hline 1. Prionostemma unguiculata & 4 th \\
2. Icacina oliviformis & 9 th \\
3. Cathormion altissimum & 13 th \\
4. Gardenia nitida & $18 \mathrm{th}$ \\
5. Milicia excels & $29 \mathrm{th}$ \\
\hline
\end{tabular}


Table 5 Same species exploited in study area and Togo, their categories and ranks.

\begin{tabular}{llll}
\hline S/N Species & $\begin{array}{l}* \text { TOGO Preferred or } \\
\text { Category 1 Species }\end{array}$ & $\begin{array}{l}* \text { TOGO Alternative or } \\
\text { Category 2 Species }\end{array}$ & $\begin{array}{l}\text { GHANA Rank in } \\
\text { present study }\end{array}$ \\
\hline 1 Anogeissus leiocarpus & & & Y \\
2. Terminalia glaucescens & $\sqrt{ }$ & & $1 \mathrm{st}$ \\
3. Vitellaria paradoxa & $\sqrt{ }$ & & 5 th \\
4. Dialium guineense & $\sqrt{ }$ & $\sqrt{ }$ & 7th \\
5. Daniellia oliveri & $\sqrt{ }$ & $\sqrt{ }$ & 9 th \\
6. Tectona grandis & & $\sqrt{ }$ & 13th \\
7. Hymenocardia acida & & $\sqrt{ }$ & 17th \\
8. Cola gigantean & & $\sqrt{ }$ & $21 \mathrm{st}$ \\
9. Parkia biglobosa & $\sqrt{ }$ & 29 th \\
10. Vitex doniana & & & 29 th \\
\hline
\end{tabular}

Sources: Refs. [8-10].

pterocarpoides. This brings to six of the non-traditional charcoal-producing species. The expansion of the range of species used by the producers appears to be a strategy to make up for the diminishing resource base of the traditional charcoal-making species. The situation would also confirm the view of Kokou et al. [9] that the choice of the resource was not only related to the energy quality but also to the availability. This would further explain the selection of Triplochiton scleroxylon. For example, a species described as soft and light with density at $15 \%$ moisture content was reported to be $24 \mathrm{lb}$. per cu ft. or $385 \mathrm{~kg} / \mathrm{m}^{3}$ compared to the density of Anogeissus leiocarpus reported as $65 \mathrm{lb}$. per cu ft. or $1,040 \mathrm{~kg} / \mathrm{m}^{3}$ [14]. According to Pereira et al. [7], the basic density can be considered as one of the main criteria for selection of species and clones for charcoal production. Some of these charcoal-making species are also sources of edible products. For example, Icacina oliviformis, one of the non-traditional charcoal-producing species, is described as a small drought-resistant shrub forming dense stands in the West African and Central African savannas. Its three edible products are fruits, seeds and tuberous roots [15].

\section{Conclusions}

The study in the Volta Region of Ghana recorded 35 species belonging to 31 genera. Five of the species are non-traditional charcoal-making species. Global warming is already posing a threat to biodiversity. Expanding the range of the woody plant species used for charcoal production means that the threat is going to be much worse with implications for people, land and biodiversity conservation. Ten of the 34 species used for producing charcoal in Togo are among the 35 species exploited in the Volta Region of Ghana. The potential threat to these ten species is implicated to be greater than the threat to the other species.

\section{References}

[1] Onishi, N. 2016. "Africa's Charcoal Economy is Cooking. The Trees are Paying." Accessed June 29, 2016. http://nyti.msp/28YCpNN.

[2] Kammen, D. M., and Lew, D. 2005. "Review of Technologies for the Production and Use of Charcoal." Accessed June 11, 2016. http://webcache.googleusercontent.com/search?q=cache: http:hedon.info/docskam.

[3] C2ES (Center for Climate and Energy Solutions). 2012. "Addressing Climate Change in the near Term: Short-lived Climate Forcers." Accessed June 11, 2016. http://www.c2es.org/science-impacts/short-lived-climateforcers?utm_source $=$ Center + for + Climate $l+$ and + Energy + Solutions + newsletter+listautm_campain $\mid=203$.

[4] Waugh, J. 2012 "Support Community Mapping for Climate Adaptation." Accessed June 11, 2016. http://www.Scidev.net/en/climate-change--and ener.

[5] van der Plas, R. 1995. "Energy Issues Burning Charcoal Issues" The World Bank Group, FDP Energy Group Accessed June 26, 2015. http://www-wds.worldbank.org/servlet/WDSContentserv 
er/WDSP/IB/1999/08/15/00000926.

[6] Abbiw, D. K. 1990. Useful Plants of Ghana. Kew: Intermediate Technology Publications.

[7] Pereira, B. L. C., Oliveira, A. C., Carvalho, A. M. L., Carneiro, A. C., Santos, L. C., and Vital, B. R. 2012. "Quality of Wood and Charcoal from Eucalyptus Clones for Ironmaster Use.” International Journal of Forestry Research. Accessed June 11, 2016. http://hindawi.com/Journals/ijfr/2012/523025.

[8] Irvine, F. R. 1961. Woody Plants of Ghana. London: Oxford University Press.

[9] Kokou, K., Nuto, Y., and Atsri, H. 2009. "Impact of Charcoal Productionon Woody Plant Species in West Africa: A Case Study in Togo.” Scientific Research and Essays Volume 4 (9): 881-893.

[10] LApez-Pujol, J., ed. 2011. "The Importance of Biological Interaction in the Study of Biodiversity." Accessed June
11, 2016. www.Intechopen.com.

[11] Hawthorne, W., and Jongkind, C. 2006. Woody Plants of West African Forests. Surrey: Kew Publishing.

[12] Hawthorne, W. D., and Gyakari, N. 2006. Photoguide for the Forest Trees of Ghana. Oxford: Oxford Forestry Institute.

[13] Kumapley, P., and Azumah, F. 2015. "Charcoal Production in a Cacao-Farming Area: Plant Species Used and Sources." Journal of Environmental Science and Engineering A4: 258-265.

[14] The Ghana Timber Marketing Board. 1969. Ghana Hardwoods. Takoradi. The Ghana Timber Marketing Board.

[15] The National Academies of Science, Engineering and Medicine. 2008. Lost Crops of Africa. Volume III. Fruits. Chapter 7 ICACINA. The National Academies Press. 